Article

\title{
Exchange rate and economic growth nexus: An impact analysis of the Nigerian economy
}

\author{
Lawali Bello Zoramawa ${ }^{*}$, Machief Paul Ezekiel ${ }^{2}$, and Aliyu Tukur Kiru ${ }^{3}$ \\ 1 Department of Economics, Sokoto State University, Nigeria ; Lawalbzoro@hotmail.com \\ 2 Marketing Department, First City Monument Bank (FCMB), Birnin Kebbi, Kebbi State Nigeria; \\ thispaul12@yahoo.com \\ 3 Principal Planning Office Department for Sustainable Development Goals (SDGs), Ministry of Planning \& \\ Budget, Kano State, Nigeria; aliyutukurkiru@yahoo.com \\ * Correspondence: lawalbzoro@hotmail.com; Tel.: (+2348065900202
}

Received: 22 January 2020; Accepted: 30 September 2020; Published: 5 October 2020

\begin{abstract}
This study examines the impact of the exchange rate, as an important determinant of economic growth in Nigeria between 1980 and 2019. Secondary data was used and sourced from the Central Bank of Nigeria (CBN) Statistical Bulletin 2016. The econometric techniques used in the analysis were: Unit Root Test, Johansen Cointegration Test, and Error Correction Model (ECM). The result revealed that exchange has a positive and statistically significant impact on economic growth at a $5 \%$ level of significance. But the result further revealed that economic openness was found to have impacted negatively on economic growth. Based on these findings it was recommended that the government through its monetary authority such as $(\mathrm{CBN})$ should redesign the existing monetary policies to maintain a stable exchange rate. Lastly, since the economic openness hurts economic growth, it is therefore suggested that the government should sustain its current efforts in diversifying the economy in the country and disregard the notion that openness generates economic growth in the country.
\end{abstract}

Keywords: Exchange Rate; Economic Openness; Economic Growth; ARDL; ECM

JEL codes: F31, G15, O40

\section{Introduction}

Several sources of economic growth have extended to include a stable exchange rate, economic openness to foreign participation, investment in physical capital, surplus labor and improvement in technological, foreign aid, investment in human capital, foreign direct investment (FDI), and increasing returns from investment and research and development. Does it matter if a country's national output rises or falls over time? For the many developing economies in West Africa, faced with many challenges particularly in growth problems the answer may be obvious. The importance of exchange rate stability in the attainment of macroeconomic policy objectives in both developed and developing economies cannot be overemphasized. Apart from being a relative price of one currency in terms of another, the exchange rate connects domestic and foreign markets for goods and assets, it also, signals the level of international competitiveness among currencies in the global market (Insah and Shiaraah, 2013). However, governments, particularly in developing economies over the years have adopted different exchange rate management policies to achieve a realistic and stable exchange rate. Thus, most of these countries experienced high exchange rate fluctuation which translates into a high degree of uncertainty or volatility. Exchange rate volatility is associated with unpredictable movements in the relative price of the economy. It also refers to the swings or fluctuations in the 
exchange rate over some time or deviations from a benchmark or equilibrium exchange rate. Exchange rate volatility is an important contributor to risk in the financial world. During the period of excessive movements in exchange rates, foreign trade and investments could be affected negatively (Ajao and Ibgekoyi, 2013, Mordi, 2006 and Insah and Shiaraah, 2013).

The problem of exchange rate volatility in Nigeria can be traced to the mid-80s when Structural Adjustment Programmes (SAP) was introduced. One of the objectives of SAP was to achieve a realistic and stable exchange rate of Naira. Since then, exchange rate determination has gone through a substantial transformation in Nigeria. Bakare (2011) asserted that before the establishment of the central bank of Nigeria (CBN) in 1958 and the establishment of the Exchange rate Control Act in 1962, foreign exchange was earned by the private sector and held in balances abroad by commercial banks that acted as agents for local exporters. The boom experienced in the 1970s made it necessary to manage the foreign exchange rate to avoid shortages. However, shortages in the late 1970s and early 1980s compelled the government to introduce some ad hoc measures to control excessive demand for foreign exchange. Among the measures is the promulgation of the Exchange Rate Control Act of 1977 and the comprehensive import supervision Scheme (CISS) in 1979.

According to Aliyu (2011) until 1989, Nigeria has adopted the following exchange rate management policies: Second Tiers Foreign Exchange Market in 1986, Dutch Auction System (DAS) in 1987, and Autonomous Foreign Exchange Market in 1988. Despite the introduction of these mechanisms, exchange rate regimes remain unfavorable in Nigeria. For instance the value of naira depreciated from an average of $\$ 0.89=\$ 1.00$ US dollar in 1985 to $\$ 2.02=\$ 1.00$ in 1986 , to $\$ 4.02=\$ 1.00$ in 1987 in the official foreign exchange market, while in the parallel market exchange rates were 4.17 $=\$ 1.00$ and $\$ 10.53=\$ 1.00$ between 1986 and 1987 respectively.

As indicated by Sanni (2006) in 1989, the CBN introduced inter-bank foreign exchange market (IFEM) and Bureau de change to broaden the scope of the foreign exchange market and to accommodate the small end-user need for foreign exchange. Also in 1990, the IFEM procedures were modified by re-introducing Dutch Auction System (DAS) with the main aim of achieving a stable exchange rate. Furthermore, 1992 CBN terminates the use of DAS and substituted it with complete deregulation of the foreign exchange market. Further reforms such as the formal pegging of the Naira exchange rate, the centralization of foreign exchange in the $\mathrm{CBN}$, the restriction of Bureau de change to buy foreign exchange as an agent of CBN were all introduced in the foreign exchange market in 1994 as a result of exchange rate volatility.

On the other hand, some of these researchers employed econometric techniques such as OLS, and 2stages Least Squares (2SLS) estimate, employing a two-way causal flow. On the other hand, empirical studies by Matthias (2004), Rodrik (1992), Levine and Renelt (1992) claimed that a higher degree of openness negatively affects the domestic economy. Finally, Battra and Slottje (1993) and Leamer (1998) suggested that open trade can be a primary source of economic downturn.

Moreover, in Nigeria, many related empirical studies have been conducted on the relationship between trade openness and economic growth (Ezeuchenne and Lawal 2017, Da'silvaand Ehinomen 2014, Babatunde et al 2013, Biala et al 2013, Ugbor, K. 2013, Alajekwu et al 2013, Adejoke et al 2013, Kingsely 2004 and Ekpo 1995) all these studies flouted the impact of the exchange rate in Nigeria. This study, therefore, incorporates the exchange rate to fill the variables gap of the existing studies. This is because the problem of exchange rate uncertainty becomes too worrying and over the years has been a cause of great concern to policymakers, policy analysts, investing firms, foreign investors, researchers, academicians, and the general public (Stephen and Sanmi, 2011). The exchange rate is the price at which the currency of one country in exchange for the currency of another country. It is one of the determinants for assessing the performance of an economy. A very strong exchange rate is a reflection of a strong and viable economy. While on the other hand, a very weak currency is a reflection of a very vulnerable and weak economy. It is one country's money that is exchanged for another country's money (Lipsey and Chrystal 2007). Mannur (2005) defined the exchange rate as the price of local currency that must be paid per unit of foreign currency. For example, the exchange rate between 
the local currency (say naira) and foreign currency (i.e. dollar) is the amount of naira needed to obtain US dollars.

\section{Literature Review}

Stancik (2007) examined the determinants of exchange rate volatility for five central and eastern European countries (CEEC-5). The objective of this study was to analyze the causes of Euro exchange rate fluctuations for these countries. The author employed the TARCH model in his attempt to investigate the extent to which trade openness, news factors, and exchange rate regimes affect exchange rate behavior in Hungary, Slovakia, Slovenia, Poland, and the Czech Republic from 1999 to 2004. He found that news factors had a great impact on exchange rate behavior in Hungary, Slovenia, and Slovakia. Moreover, Slovenia had a large potential in its openness and does not have any effect on Hungary and Slovenia. On the other hand, Poland and the Czech Republic cannot depend on economic openness in reducing their exchange rate volatility and news factors had little effect on the exchange rate volatility of these countries. Also, he observed that key changes in exchange rate regimes have a significant effect on exchange rate movements. Finally, he discovered that the trends of the exchange rate in each country depend upon the policy adopted by the monetary authorities.

Al-Samara (2009) investigates the determinants of real exchange rate volatility in Syria from 1980 to 2008. His objective was to identify the principal factors suggested in many theoretical pieces of literature, which includes relative productivity, government expenditure, and terms of trade, trade openness, and net foreign assets. To empirically examine these variables, the author employed VECM and $\mathrm{ARCH}$. His result reported that relative productivity, total investment, and the oil price has a positive impact on exchange rate volatility; while government expenditure was found to negative impact. The author suggested that other researchers should include other factors that have not been captured in this study for perhaps they might have potential explanations.

Insah and Chiaraah (2013) empirically investigated the factors affecting real exchange rate volatility in Ghana for the period of 1980 to 2012. The variables of their choice include; government expenditure, money supply, domestic debt, and external debt. To examine the relationship, the authors employed the ARDL model. Their findings revealed that there exists a positive relationship between government expenditure and exchange rate volatility, while money supply, domestic and external debts were negatively related to exchange rate volatility. The authors recommended that government expenditure should cut down its expenditure to control the persistence trends in the exchange rate.

Insah and Chiaraah (2013) empirically investigated the factors affecting real exchange rate volatility in Ghana for the period of 1980 to 2012. The variables of their choice include; government expenditure, money supply, domestic debt, and external debt. The authors employed the ARDL model. Their findings have shown that there is a positive relationship between government expenditure and exchange rate volatility, while money supply, domestic and external debts were negatively related to exchange rate volatility. The authors recommended that government expenditure should cut down its expenditure to control the persistence trends in the exchange rate.

Asiama and Kumah (2010) examine the degree of influences upon which productivity, fiscal balance, current account balance, terms of trade, openness, oil prices, public consumptions, foreign direct investment and, foreign aids affects exchange rate variability in African countries throughout 1980 to 2008. The objective of a study was to investigate whether there is evidence of consistency between the theoretical and empirical framework. To test the variable, the authors utilized a panel cointegration approach. The study reveals that both theoretical and empirical frameworks were very consistent, and the real exchange rate was strongly influenced by openness, terms of trade, and oil prices.

Ajao and Igbekoyi (2013) examined the degree of influence of real exchange rate, productivity, trade openness and government expenditure, real interest rate, and money supply on real exchange rate volatility in Nigeria for the period between 1981 and 2008. Using GARCH and ECM, their empirical results indicate that real exchange rate, trade openness, government expenditure, real 
interest rate have a positive impact on exchange rate volatility in Nigeria with exception of money supply and productivity.

Bala and Asemota (2013) empirically examined the exchange rate of naira volatility against the United States dollar (USD), British Pound Sterling (BPS), and Euro, using monthly time series data from 1985 to 2011. The authors in the analysis used the GARCH model with exogenous breaks. The results showed the evidence of leverage effect. They recommended that monetary authority should take into cognizance the factors influencing exchange rate volatility within and outside the economy in design exchange rate policies in Nigeria.

Hussain and Asghar (2014) empirically examine the causal connection among financial development, openness, and economic growth in developing countries for the period 1978 to 2012. The study employed a panel unit root test, Panel cointegration test, and Panel causality test, and ADF as techniques of analysis. The variables controlled in the analysis are Financial Development (FD), Trade Openness (TO), Foreign Direct Investment (FDI), Human Capital (HC), Gross Capital Formation $(\mathrm{GCF})$, and Interest $(\mathrm{R})$. The finding of the study indicated that there is strong evidence of the long-run relationship between FD and economic growth and a bi-directional causality between FD and FDI. But, trade openness has a positive and statistically significant impact in all countries. The study, therefore, recommended the introduction of effective policies that can promote trade between developing countries.

Altee, Adam, Esmaeel, and Saled (2014) analyzed empirically the impact of financial development and trade openness on economic growth in an open economy of the Sultanate of Oman through the period 1972 to 2012. They engaged Johansen and Juselius (JJ), VAR framework, and Granger causality tests as their techniques of analysis. The objective of their work is to find out how financial development influences economic growth in the Sultanate of Oman during the period under investigation. The result of the analysis showed a positive and statistically significant influence between economic growth and the controlled variables. On the other hand, the result indicates a unidirectional causality running from trade openness to economic growth.

Da'silva and Ehinomen (2014) empirically investigated the nexus between economic openness and productivity growth in Nigeria for the period of 1970 to 2010. Their objectives were to find out the ways that enable the country to improve its productivity. The variables of their choice were real GDP, openness, exchange rate, real interest rate, and unemployment. The authors employed the ordinary least square (OLS) in the analysis. Their result indicated that a positive and statistically significant relationship exists between trade openness and economic growth. They recommended the following: economic diversification, and accurate utilization of export revenue. They further stressed the need to encourage export promotion policies.

Alajekwu, Ezeabasili and, Nzotta (2013) empirically investigated the relationship between trade openness, stock market development, and economic growth in Nigeria from 1986 to 2011. The study used Johansen multivariate co-integration and the granger causality test as the techniques of analysis. The result shows that there is a negative and statistically not significant relationship between trade openness and economic growth in Nigeria. The study also recommended that the government should develop policies that will create a friendly business environment where investors will be at home with the legal and financial plus trading framework.

Adejoke, Ibiyemi, Olusuyi, and, Babatunde (2013) empirically examined the effect of trade openness and financial investment on economic growth in Nigeria between 1960 and 2011. It was observed that long-run positive and statically significant relationship exists among trade openness, FDI, and economic growth in Nigeria. Emanating from the finding the study recommended that structural trade-oriented policy should be adopted to enhance economic growth in Nigeria via high export flows to accumulate more foreign proceed to boost output growth in Nigeria. 


\section{Methods}

The model used in this study is the multiple regression analysis. The theoretical bases of this model are found in the works of Bremer (2012), according to him, the model describes how a single response variable, say $\mathrm{Y}$ depends on many predictor variables, say $\mathrm{X} 1, \mathrm{X} 2, \ldots . \mathrm{Xn}$

This according to Bremer (2012) this can also be written as:

$$
Y=\beta 0+\beta 1 \times 1+\beta 2 x 2+\cdots \beta n x n+U .
$$

These are expressed as follows:

$$
R G D P_{t}=\beta_{0}+\beta_{1} E X C R_{t}+\beta_{2} \operatorname{OPENS}_{t}+\mu_{t},
$$

where RGDP, is the real Gross Domestic Product, EXCR is the Exchange Rate, OPENs, is the Openness, and $\beta$ is the beta sign, ut the white noise.

Also, different techniques of data analysis were used in carrying out this empirical analysis on the assessment of the contribution of exchange, rate, and economic growth in Nigeria. These techniques include the autoregressive distributed lag (ARDL) models, error correction method (ECM), vector autoregressive (VAR) models, vector error correction method (VECM), simultaneous equation model, and the Johansen cointegration approach to analyze the impact of exchange rate on economic growth in Nigerian. This research work employs the autoregressive distributed lag (ARDL) model.

The ARDL model is given as:

$$
\mathrm{Yt}=\mathrm{m}+\alpha 1 \mathrm{yt}-1+\beta 0 \mathrm{xt}+\beta 1 \mathrm{xt}-1+\mathrm{ut},
$$

where yt and xt are stationary variables, and ut is white noise. The White-noise process: A sequence $\{u t\}$ is a white-noise process if each value in the sequence has a mean of zero, a constant variance, and is serially uncorrelated. The sequence $\{u t\}$ is a white-noise process if for each period $t$,

$$
\begin{gathered}
\mathrm{E}(\mathrm{ut})=\mathrm{E}(\mathrm{ut}-1)=\cdots=0 \\
\mathrm{E}(\mathrm{u} 2 \mathrm{t})=\mathrm{E}(\mathrm{u} 2 \mathrm{t}-1)=\cdots=\sigma 2 \\
\mathrm{E}(\mathrm{utut}-\mathrm{s})=\mathrm{E}(\mathrm{ut}-\mathrm{jut}-\mathrm{j}-\mathrm{s})=0, \text { for all } \mathrm{u}
\end{gathered}
$$

\subsection{Autoregressive Distributed Lag Bound Testing Approach}

To empirically analyze the long-run relationship and short-run dynamic interactions among the variables of interest (Real Gross Domestic Products, exchange rate, and economic openness) ARDL was applied. A further advantage of the ARDL model over previous and traditional co-integration methods is: All variables of the model are assumed to be endogenous and the short-run and long-run coefficients of the model are estimated simultaneously (Nikolaos, 2011). The ARDL approach to cointegration analysis involves the estimation of the Unrestricted Error Correction Model (UECM). Hence the ARDL model for testing the relationship between exchange rate, economic openness and economic growth can be written as:

ADRL equation for the First model

$$
\triangle R G D P_{t}=\alpha_{0}+\alpha_{1} R G D P_{t-1}+\alpha_{2} E X C R_{t-1}+\alpha_{3} O P E N S_{t-1}+\mu_{t},
$$

where RGDP is the real Gross Domestic Product, EXCR is the Exchange Rate, OPENS is the Openness, and $\mathrm{ut}$ is a white-noise, $\Delta$ is the difference parameter, $\mathrm{t}$ is period, and $\alpha$ and $\beta$ are the respective parameters of the model.

ARDL Equation for Second Model

$$
\begin{gathered}
\triangle \text { OPENS }_{t}=\alpha_{0}+\alpha_{1} \text { OPENS }_{t-1}+\alpha_{2} \text { EXR }_{t-1}+\sum_{n=i}^{m=1} \beta_{1} \Delta \text { OPENS }_{t-i}+ \\
\sum_{n=i}^{m=1} \beta_{2} \Delta \text { OPENS }_{t-i}+\sum_{n=i}^{m=1} \beta_{3} \Delta E X R_{t-i}+\mu_{t}
\end{gathered},
$$




$$
\begin{aligned}
& \triangle E_{X X}=\alpha_{0}+\alpha_{1} \operatorname{EXR}_{t-1}+\alpha_{2} \text { OPENS }_{t-1}+\sum_{n=i}^{m=1} \beta_{1} \Delta \operatorname{OPENS}_{t-i}+ \\
& \sum_{n=i}^{m=1} \beta_{2} \Delta E X R_{t-i}+\mu_{t}
\end{aligned}
$$

where: $\Delta$ is the first difference operator, $\alpha_{0}$ is the drift component, $\alpha_{1}$ to $\alpha_{3}$ in each equation represent the coefficients of level lagged value of the explanatory variables captured in the model, and $\beta_{1}$ to $\beta_{3}$ in each equation, are the vector of the coefficient of the first difference lagged values of the variables captured in the model. From the first until the eighth expression ( $\beta_{1}$ to $\left.\beta_{3}\right)$ on the right-hand side correspond to a long-run relationship. The remaining expressions with the summation sign $\left(\alpha_{1}-\alpha_{3}\right)$ represent the short-run dynamics of the model.

\section{Results and Results}

It is important to check the time series property of the variables before estimating the model to avoid the spurious result. Table 1 shows the result of the stationarity of the ADF unit root test and the results of the ARDL bound test for cointegration are presented in Table 2 and Table 3 respectively, while Table 4 presents the results of the Granger Causality Test.

\subsection{Descriptive Statistics}

4.1.1 Summary Statistics of the Variables Used for Estimation

Table 1. Results of Descriptive Statistics

\begin{tabular}{cccccc}
\hline Variable & Observations & Mean & Std. Deviation & Minimum & Maximum \\
\hline LRGDP & 36 & 13.45592 & 0.220447 & 13.18306 & 13.84374 \\
LEXR & 36 & 1.619938 & 0.593347 & -0.129791 & 2.100606 \\
OPEN & 36 & 0.159720 & 0.169518 & 0.000879 & 0.578149
\end{tabular}

Source: Author's computation 2020

The summary of the data used in estimating the relationship between the variables is presented in Table 1. The mean (average rates) of real GDP, exchange rate, and openness all have positive values. This scenario indicating that we have more of an increase than a decrease in the changes among the variables. This indicates that Nigeria is witnessing an important improvement in its economic growth with the real gross domestic product having an estimated mean higher than all other variables during the period under review. The exchange rate has a higher standard deviation, which suggests that, the degree of variability of the exchange rate higher than that of any other variable in the distribution. However, economic openness has both a lower mean and standard deviation, which shows that the dispersion of the data is closer to its mean.

\subsubsection{Unit Root Test}

Based on the results presented in Table 2, all the variables are not stationary at their level values except the exchange rate (LEXR). However, the variable became stationary after taking its first difference. Therefore, the conditions for the application of the autoregressive distributed lag (ARDL) bound testing to cointegration is met which is the presence of the variables both at the level and first difference. However, it is worth noting that the ARDL bound test can only be applied when variables are not integrated of order two $I(2)$. 
Table 2.Results of Unit Root Test

\begin{tabular}{cccc}
\hline Variable & ADF at level & ADF at First Difference & Remark \\
\hline LRGDP & 1.352038 & $-4.838580^{* * *}$ & $\mathrm{I}(1)$ \\
LEXR & $-3.489660^{* * *}$ & & $\mathrm{I}(0)$ \\
LOPEN & -1.323268 & $-6.278546^{* * *}$ & $\mathrm{I}(1)$ \\
\hline
\end{tabular}

\subsubsection{Bound Test for Autoregressive Distributed Lag (ARDL) Cointegration Test}

Table 3 presents the results of the ARDL bound test along with the critical values bond at the lower part of the Table. The results revealed that all the models have shown evidence of cointegration among the variables with the exception 3, where exchange rate (LEXR) were taken as dependent variables, respectively. The LEXR model revealed inconclusive because of the F-statistic fall in between lower and upper bounds.

Table 3. Results of Autoregressive Distributed Lag (ARDL) Cointegration Test

\begin{tabular}{ccc}
\hline Estimated Models & F-Statistics & Remark \\
\hline FLrGDP/(LEXR, LOPEN) & 5.648921 & Cointegration \\
FLEXR/(LRGDP,LEXP,LOPEN) & 2.429229 & $\begin{array}{c}\text { Inconclusive } \\
\text { Cointegration }\end{array}$ \\
\hline FLOPEN/(LGRDP,LEMPR,LEXR,LFDI,LEXP,LIMP) & 6.562931 & \\
\hline Critical Values Bounds & & Upper Bound \\
\hline $10 \%$ & Lower Bound & 2.94 \\
$5 \%$ & 1.99 & 3.28 \\
$2.5 \%$ & 2.27 & 3.61 \\
$1 \%$ & 2.55 & 3.99 \\
\hline
\end{tabular}

Source: Author's computation.

\subsubsection{Short-Run Coefficients for ARDL}

Table 4 presents the results of the short-run impact of the variables on the dependent variable. The coefficient exchange rate though positive but insignificant impacts on economic growth. Meanwhile, the coefficient of openness has a negative and significant impact on economic growth at a $1 \%$ level of significance. The coefficient of error correction model (ECM (-1)) revealed a correct sign and statistically significant which measures the speed of adjustment of the dependent variables at which equilibrium is restored. The results implied that $52 \%$ of any disequilibrium in the economic growth is corrected within a lag (one year in this study).

Table 4. Results of Short-run Coefficients

\begin{tabular}{ccccc}
\hline Variable & Coefficients & Std. Error & T-statistic & P-value \\
\hline D(LEXR) & 0.005790 & 0.002730 & 2.121224 & 0.522 \\
D(LEXR(-1) $)$ & -0.002070 & 0.002663 & -0.777521 & 0.4498 \\
D(LEXR(-2) & 0.007372 & 0.001787 & 4.125370 & 0.0010 \\
D(LOPEN) & -0.422926 & 0.012248 & -34.530701 & 0.0000 \\
D(LOPEN(-1) & 0.030316 & 0.013552 & 2.236999 & 0.0421 \\
D(LOPEN(-2) & 0.008462 & 0.005007 & 1.690078 & 0.1131 \\
ECM(-1) & -0.519423 & 0.174225 & -8.721029 & 0.0000 \\
\hline
\end{tabular}

Source: Author's computation.

\subsubsection{Long-run Coefficients for ARDL}

The long-run impacts of the coefficients are presented in Table 5. The results revealed that the exchange rate has positive and statistically significant impacts on economic growth in the long run at 
a $5 \%$ level of significance. However, openness has been found to have impacted negatively on economic growth in the long run.

Table 5. Results of Long run Coefficients

\begin{tabular}{ccccc}
\hline Variable & Coefficient & Std Error & T-statistic & P-value \\
\hline LEXR & 0.004526 & 0.002129 & 2.125774 & 0.0518 \\
LOPEN & -0.431019 & 0.004040 & -106.677467 & 0.0000 \\
CONSTANT & 0.366414 & 0.103715 & 3.532882 & 0.0033 \\
\hline
\end{tabular}

Source: Author's computation.

\subsubsection{Result of Diagnostic Tests}

Diagnostic tests have been conducted to check the reliability of the results. Based on the results presented in Table 6, the findings are reliable because it passed all the major tests in the form of normality, serial correlation, heteroskedasticity, and function form.

Table 6. Results of Diagnostic Tests

\begin{tabular}{ccc}
\hline Test & Test Statistic & P-value \\
\hline Normality & 1.7099 & 0.4253 \\
Serial Correlation & 0.8841 & 0.7078 \\
Heteroskedasticity & 1.1652 & 0.3914 \\
Functional Form & 1.7795 & 0.0985 \\
\hline
\end{tabular}

Source: Author's computation.

\section{Conclusions}

Nigeria's economy is characterized as an import-dependent economy. It is very essential to understand the factors underlying the factors that determine the sources of economic growth to give room for the government authorities, experts, and policymakers to device and design strong policies that will ensure sustainable economic growth. This is because, in the period of economic crisis (economic recession), international trade and investment, production and job creation, the price level could be affected negatively. It is in this respect that this study an assessment of the impact of the exchange rate and trade openness on economic growth in Nigeria is carried out.

The ARDL result reveals that: Economic openness; do not cause economic growth throughout the study period. However, economic growth is caused by a stable exchange rate, during the study period.

From the above-mentioned, it has been empirically revealed that the exchange rate is the main determinant of economic growth in Nigeria throughout the study period. Based on these findings, the study, therefore, made the following recommendations: First, the monetary authority such as (CBN) shall reform the existing monetary policies to maintain a stable exchange rate due to its influence on economic growth. This is because when there is a stable exchange rate in the economy, it is expected that there will be stable and increased economic activities such as investment, production, and job creation. Second, since the economic openness harms economic growth, this is because our imports are greater than exports; it, therefore, recommended that there is a need for the government to sustain its current efforts in diversifying the economy to achieved exports led economic growth. For instance, the manufacturing industries, and the agricultural sector should be given priorities to produce more in such a way that the country can produce a surplus for exportation and not only to produce the consumption goods particularly in agriculture, and to stop the importation of the commodities in which we have its primary commodity. For instance, rice production, sugar production, leather production, and much more, since Nigeria is blessed with fertile land and a large number of rice farmers, sugarcane farmers, a huge number of animal skin, robber timber, kinds of cotton, and many more. The is no need for the importation of rice and such products/commodities into the country and 
hence the government should find and assist the real farmers in cash and kind to help them produce more up to the exportation level.

Author Contributions: The contributions of individual authors are as follows: Conceptualization, Ezekiel; methodology, Zoramawa.; software, Zoramawa; validation, Zoramawa., and Ezekiel; formal analysis, Zoramawa.; investigation, Kiru; resources, Kiru; data curation, Zoramawa.; writing-original draft preparation, Zoramawa; writing - review and editing, Zoramawa; visualization, Zoramawa; supervision, Zoramawa; project administration, Zoramawa; funding acquisition, Zoramawa, Ezekiel and Kiru. All authors have read and agreed to the published version of the manuscript.

Funding: This research received no external funding.

Acknowledgments: I, Lawali Bello Zoramawa would like to thank other authors of this paper Machief and Aliyu, and my good friend Adamu Hassan (PhD. Student); my dear wife Asm'u Engineer Musa Mutawalle Dogon Daji, my Mother, Aisha Abdullahi, and my sons Muhammad Lawal Zoramawa and Sadeeq Lawal Zoramawa for their elegant contribution that without it, the research may not be possible.

Conflicts of Interest: This research work is conflict free and does not attract any external funding.

\section{References}

Altee, A.H., Adam, M.H., Esmaeel, S.E. \& Saled, M.S. (2014). Financial development trade Openness and economic growth: Evidence from Sultanate of Oman. Journal of economic and sustainable development, 5 (23), ISSN 22222855

Alajekwu, B.U., Ezeabasili, N. V., \& Nzotta, M. S. (2013). Trade openness stock market development and economic growth: Empirical Evidence. Journal of Research, Finance and Accounting, 4(3), 2222-1697

Adejoke, S.I., Ibiyemi, O., Olusuyi, E.A., \&. Babatunde, A. G., (2013). Trade openness and economic growth in Nigeria: An empirical analysis. International Journal of Humanities and Social Science Invention, 2(6), 2319-7722. www.ijhssi.org.

Alajekwu, B.U., Ezeabasili, N. V.,\& Nzotta, M. S. (2013). Trade openness, stock market development, and economic growth: Empirical Evidence. Research Journal of Finance and Accounting, 4(3), 2222-1697

Adejoke, S.I., Ibiyemi, O., Olusuyi, E.A., \&. Babatunde, A. G., (2013). Trade openness and economic growth in Nigeria: An empirical analysis. International Journal of Humanities and Social Science Invention, 2(6), 2319-7722.

Asiama J.P. and Kumah F.Y., (2010). Determinants of real exchange rate movements: Evidence from a panel of African countries. West African Finance and Economic Review, 2,(2)

Ajao M.G and Igbokoyi O.E. (2013). The determinants of real exchange rate volatility in Nigeria. Journal of International Studies, ISSN-2281-4612

Bala D. A., \& Asemota J.O., (2013). Exchange rate volatility in Nigeria: Application of GARCH Models with Exogenous Break. CBN Journal of Applied Statistics, 4 (1)

Hussain, Z. \& Asghar, N. (2014) Financial development, trade openness, and economic growth in developing countries: Recent evidence from panel data. Pakistan journal of economic and social review, 52(2), 99-126.

Bremer, M. (2012). Multiple linear regression: Math 261A-Spring 2012; supplement multiple regression.Central Bank of Nigeria (2003).Statistical Bulletin. Abuja: Central Bank of Nigeria.

Batra R. and D.J Slottje. (1993). Trade policy and poverty in the United States: theory and evidence, 19741990.Review of International Economics 1,189-208.

Babatunde, M.A., Bukula, H., Olodo, O.A. \& Ibraheem, K. (2013): An empirical study of growth through trade: Nigerian evidence. Arabian journal of business and management review (OMAN Chapter), 3(5).

Biala, I.M., Suboir, K. \& Olaifa, G.F. (2013). Trade liberalization, and economic growth in Nigeria: A cointegration analysis. Journal of Business, Economics, and Finance. 2(3),2146-7943.

Christopher, E. (2014). Impact of Trade Openness on the output growth in the Nigerian. Economy British journal of economics, management $\mathcal{E}$ trade 4(5), 755-768, 2014

Dasilva, D.\&Ehinomen, C. (2014).Impact of Trade openness on the output growth in Nigeria. British Journal of Economics, Management, and Trade, 4(5), 755-768.

Elenya, K. \& Jude, O. (2013). Trade openness and economic growth: A comparative analysis of the pre and poststructural adjustment program (SAP) in Nigeria. Asian Journal of Business and Economics, 2(4), 2231-3699.

Ezeuchenne, K., \& Lawal, O.E. (2017). International trade and economic growth in Nigeria. IOSR Journal of Humanities and Social Science. 22(6), 33-43 www.iosrjournals.org. 
Nnadozie, E.U. (2013). Does trade cause growth in Nigeria?Journal of African financial and economic development.

Ekpo, A.H. (1995). Exports and economic growth in Nigeria. Journal of economics and management, 100-115. Insah B. (2013). Modeling real exchange rate volatility. Journal of economics and sustainable development, 4 (6).

John. T. \& Ogege, M. (2012). Nigerian foreign trade policy: Its Impact on non-oil exports. Journal of economics and international finance, $4(8)$.

Kingsley, O.K. (20014). Is trade openness valid for Nigeria's long-run growth? A co-integration approach. Working Papers, Journal of African Institute for Applied Economics.

Lipsey, R. \& Chrystal A. (2007). Economics Indian

Leamer, E.E., (1998). Measures of openness. Baldwin, R.E. (Ed.), Trade Policy Issues, and Empirical Analysis. The University of Chicago Press, Chicago, 147- 204.

Mannur, H.G. (2005). International Economics, 266-276.

Opurk, O. C. \& Edoum, G. S. (2013). Economic growth factors in Nigeria: The role of global trade. American Journal of Humanities and Social Science, 1(2), 51-55.

Rodrik, D. (1992). The limits of trade policy reforms in developing countries. Journal of economic perspectives, 6(1), 87-105.

Sinha, D., and Sinha, T. (2000). Openness investment and economic growth in Asia. The Indian Economic Journal 49 (4), 110-117

Ugbor, I.K. (2014). Trade openness and economic growth in Nigeria: An Impact. Asian journal of business and economics, 3(10), 2241-3602

Wacziarg, R. (2001). Measuring the dynamic gains from trade: World Bank Economic Review, 15 (3), $393-429$.

Yanikayya, H. (2003).Trade openness and economic growth: A cross country empirical investigation. Journal of Development Economics, 72(5), 57-89.

(C) 2020 by the authors. This article is an open-access article distributed under the terms and conditions of the Creative Commons Attribution(CC BY) license (http://creativecommons.org/licenses/by/4.0/). 